(C) The Author(s) 2017. This is an Open Access article, distributed under the terms of the Creative Commons Attribution licence (http://creativecommons.org/licenses/by/4.0/), which permits unrestricted re-use distribution, and reproduction in any medium, provided the original work is properly cited.

\title{
Denis Burkitt and the origins of the dietary fibre hypothesis
}

\author{
John H. Cummings ${ }^{1 *}$ and Amanda Engineer ${ }^{2}$ \\ ${ }^{1} J a c q u i$ Wood Cancer Centre, Ninewells Hospital and Medical School, Dundee DD1 9SY, UK \\ ${ }^{2}$ Wellcome Library, 183 Euston Road, London NW1 2BE, UK
}

\section{Abstract}

For more than 200 years the fibre in plant foods has been known by animal nutritionists to have significant effects on digestion. Its role in human nutrition began to be investigated towards the end of the 19th century. However, between 1966 and 1972 , Denis Burkitt, a surgeon who had recently returned from Africa, brought together ideas from a range of disciplines together with observations from his own experience to propose a radical view of the role of fibre in human health. Burkitt came late to the fibre story but built on the work of three physicians (Peter Cleave, G. D. Campbell and Hugh Trowell), a surgeon (Neil Painter) and a biochemist (Alec Walker) to propose that diets low in fibre increase the risk of CHD, obesity, diabetes, dental caries, various vascular disorders and large bowel conditions such as cancer, appendicitis and diverticulosis. Simply grouping these diseases together as having a common cause was groundbreaking. Proposing fibre as the key stimulated much research but also controversy. Credit for the dietary fibre hypothesis is given largely to Burkitt who became known as the 'Fibre Man'. This paper sets out the story of the development of the fibre hypothesis, and the contribution to it of these individuals.

Key words: D. P. Burkitt: H. C. Trowell: T. L. Cleave: G. D. Campbell: N. S. Painter: A. R. P. Walker: Dietary fibre: Non-communicable diseases

\section{Introduction}

Denis Parsons Burkitt arrived back in England on 14 February 1966 with his wife Olive and three daughters. He had worked in Africa as a surgeon for 20 years and had a worldwide reputation following his description of the occurrence of a lymphoma, primarily of the jaw, which occurred with lethal consequences in young children ${ }^{(1,2)}$. At the Mulago Hospital in Kampala where patients were admitted from a wide surrounding area Burkitt had observed that the tumour occurred only in certain locations, which shared common attributes of altitude, temperature and rainfall. Together with the expertise of the pathologist Dr Mark Epstein from London, Burkitt proposed that this tumour was due to a virus and he went on to show that it could be treated with relatively low doses of existing cancer chemotherapeutic agents. It was officially designated as Burkitt's lymphoma in 1963 by the Union for International Cancer Control (UICC). This was no one-off act of serendipity. Burkitt was fascinated by the geographical patterns of disease and had already published his observations of the distribution of other surgical conditions ${ }^{(3-5)}$. He continued to write about the possible causes of these diseases, particularly cancer, up to and after his return to England ${ }^{(6,7)}$.

Burkitt left Africa largely because of the changes that were occurring in post-independence Uganda. His intention was to continue his research into the occurrence and distribution of cancer in Africa with support from the UK's Medical Research
Council (MRC). Fibre was not on his agenda ${ }^{(8)}$ despite there being more than 180 years of literature on the subject ${ }^{(9-11)}$ nor was the notion that diet could have a role in the cause of cancer or other common diseases. Yet over the next 5 years he became convinced of its importance and, using his surgical knowledge, expertise in the geography of diseases and some experimental work, showed that lack of fibre was a determinant of bowel cancer risk ${ }^{(12)}$. As a result of his wide-angle vision, enquiring mind and interactions with many people, other conditions including diverticular disease, irritable bowel syndrome, appendicitis, varicose veins, haemorrhoids, diabetes, obesity, atherosclerosis and dental caries were added to the fibre hypothesis. Burkitt became known as 'The Fibre Man' (Fig. 1) ${ }^{(13)}$ and travelled the world to talk about fibre, diet and the prevention of the non-communicable diseases of Western culture.

How did Burkitt over a period of only 6 years come to understand dietary fibre and weave it into an hypothesis for the prevention of the major diseases of Western culture? And get the credit for it? Fibre had a long history and there was wealth of literature written about it by animal and human nutritionists and medical scientists ${ }^{(14)}$. Between 1966 and 1972 there were five people, Surgeon Captain T. L. (Peter) Cleave, Dr G. D. Campbell, Dr Neil Stamford Painter, The Rev Dr Hubert Carey (Hugh) Trowell and Dr A. R. P. (Alec) Walker, who more than any others, were instrumental in forging the ideas in Burkitt's mind. When did

Abbreviation: MRC, Medical Research Council.

* Corresponding author: John H. Cummings, email j.h.cummings@dundee.ac.uk 


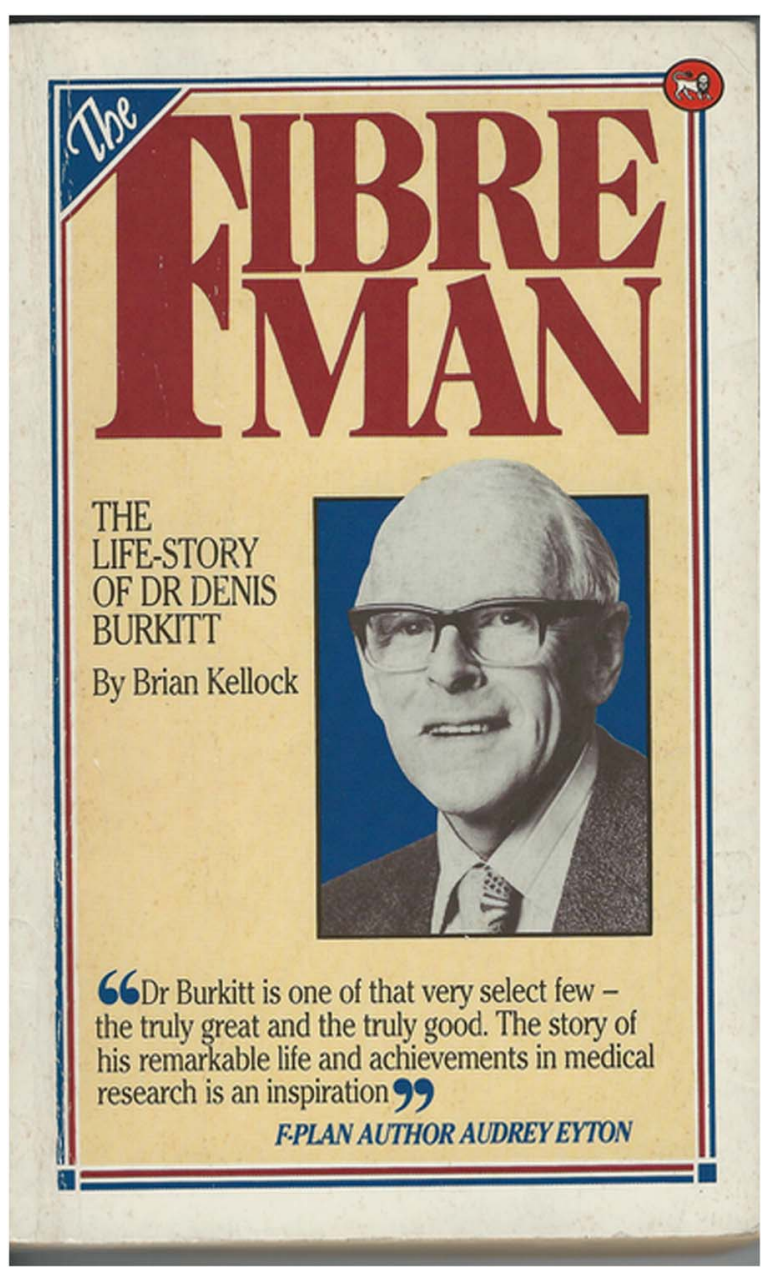

Fig. 1. The Fibre Man by Brian Kellock ${ }^{(13)}$, published in 1985.

Burkitt first meet these people, how did he interact with them and what was their contribution to the fibre story?

\section{Surgeon Captain T. L. (Peter) Cleave MRCP, RN (1906-1983)}

Perhaps most influential was Peter Cleave. Born into a naval family, both his father and brother being naval officers, he was educated at Clifton College Bristol then the Bristol Royal Infirmary. He qualified in Medicine from St Mary's Hospital London in 1928, having been commissioned into the Navy in 1927 as Surgeon Lieutenant. He remained a naval officer all his working life, retiring in 1962 as Surgeon Captain and Director of Medical Research. Although credited by some as the originator of the fibre hypothesis ${ }^{(15)}$, he saw sugar as the main obstacle to health but nevertheless introduced Burkitt to one very important concept, that if a group of diseases occur together in the same population or individual they are likely to have a common cause.

Cleave became known initially for his use of natural bran to treat constipation in sailors, which he started during the Second World War, as medical officer on the battleship King George $\mathrm{V}^{(16)}$. Using bran to treat constipation was not new in that the laxative properties of bran and wholemeal bread had been known for centuries. However, he was an original thinker, a great admirer of Charles Darwin, and from his observations of the health of contrasting populations around the world gradually developed his theories of the cause of 'modern' diseases. Between 1941 and 1962 Cleave set out his developing ideas on the cause of neoplasms ${ }^{(17)}$, peptic ulcer, CHD and varicose veins. In the spring of 1956 he outlined in a paper in the Journal of the Royal Naval Medical Service his belief that 'our neglect of natural principles was the root cause of the ills of Western society ${ }^{(18)}$. This is a long and discursive article where Cleave focuses on diet, which he says has moved from its natural state for two main reasons, 'the first being cooking and the second being the concentration of the food by machinery'. He singles out carbohydrates particularly because of the milling of wheat to produce white flour and the refining of sugar cane to produce raw sugar. These processes he proposes lead to overconsumption although less cogently he defends fat in butter and margarine as natural because the '...fat in meat occurs in pure form'. The consequences of this overconsumption of refined carbohydrates Cleave says, results in '...dental decay, peptic ulcer, diabetes, obesity, constipation and intestinal toxaemia', which he uses as examples for his general hypothesis. He describes the possible mechanisms whereby sugar and refined flour lead to ill-health and mentions 'fibrous foods' only briefly in the context of gum disease and 'removal of carbohydrate pulp' as contributing to constipation, haemorrhoids and varicose veins but does not at any stage invoke fibre as important. His arguments include historical references, food consumption data, his own observational epidemiology and some physiology but little in the way of experimental evidence. Cancer is hardly mentioned here nor is CHD. He goes on to talk about what he considers to be a healthy diet and concludes by restating his key premise that it is overconsumption of refined carbohydrates that is the key.

How the scion of a naval family should develop these ideas is unclear although he was apparently already giving dietary advice to his family whilst still at school ${ }^{(19)}$. At the Bristol Royal Infirmary one of his teachers, Rendle Short, had written a scholarly article for the British Journal of Surgery on 'The causation of appendicitis' in which he concluded '...that the cause is the relatively less quantity of cellulose eaten...(20) ${ }^{, 20}$ This is a long way from overconsumption of white flour and sugar but Rendle Short's influence may have started a young Cleave to take an interest in the distribution of diseases worldwide and diet as a factor in their cause.

Cleave retired from the Navy in 1962 and began work on a book that was to encapsulate all his ideas and bring him to the attention of the medical profession more than any of his previous writings, namely Diabetes, Coronary Thrombosis and the Saccharine Disease ${ }^{(21)}$. Published in 1966, the first chapter starts by saying that 'This work is based on the Darwinian theory of evolution.' Cleave uses data on sugar consumption worldwide and changes in flour milling practices in the nineteenth century to make the point that the greatest alterations to our diet from the '...natural state...' have occurred quite recently in evolutionary terms with the refining of carbohydrates to produce white flour and sugar. He suggests that overconsumption of these carbohydrates is due to their concentrated state in foods and that the rapidity of the change on an evolutionary time scale had led to 
maladaptation by the body and to a group of diseases, which together he proposes to be a single 'Saccharine Disease', the manifestation of which depends on '...personal build in the parts of the body affected'.

The diseases included in this concept are listed in Cleave's 1966 edition (Table 1) ${ }^{(21-23)}$. Fibre is not mentioned in the Table nor is it included in the index. It is referred to in the chapter on dental caries and mentioned in the context of bowel habit and of diverticulitis but in discussion of diabetes, coronary thrombosis, peptic ulcer and infection with ' $B$ Coli' Cleave stresses overconsumption of white flour and sugar, with fibre not considered to be a factor. Thus in neither the 1966 edition of his book, nor his paper in 1956, does Cleave implicate fibre.

\section{G. D. Campbell MD, FRCP, FRS (South Africa) (1925-1998)}

The 1966 edition of Cleave's book included a co-author, Dr George D. Campbell. Known to everyone as 'GD', Campbell was born in Durban and after qualifying in medicine in

Table 1. Development of Peter Cleave's concept of the saccharine disease as given in the three editions of his book in 1966, 1969 and 1974 (the three tables from the books show clearly the absence of fibre from the first edition and progressive inclusion thereafter)

1966 (p. 11) $^{(21)}$

Dental caries and parodontal disease ('pyorrhoea')

Peptic ulcer

Obesity

Diabetes

Colonic stasis, with its complications of varicose veins and haemorrhoids.

Coronary thrombosis

Probably many primary $B$. coli infections, and certain other conditions

1969 (p. 12) (23)

From overconsumption:

Diabetes

Obesity

Coronary thrombosis

Primary B. coli conditions

From the removal of fibre:

Dental caries and parodontal disease

Colonic stasis, with its complications of varicose veins, haemorrhoids, and diverticular disease

From the removal of protein:

Peptic ulceration

1974 (p. 17) $)^{(22)}$

1. By the removal of fibre:

a. Simple constipation (intestinal stasis), with its complications of venous ailments (varicose veins, deep vein thrombosis, haemorrhoids, and varicocele), diverticular disease, and, in part, cancer of the colon

$b$. Dental caries (in conjunction with the taking of sugar) and periodontal disease

2. From over-consumption:

Diabetes

Obesity

Coronary thrombosis

Primary E. coli infections and gallstones

3. From the removal of protein:

Peptic ulceration

* Bacillus coli was first isolated from human faeces by Escherich in 1885 and thought to be non-pathogenic. It was subsequently renamed Escherichia coli. It is probably the most studied species known, some members of which are highly pathogenic.
Edinburgh, UK, war service in the South African Artillery, a year in Philadelphia, USA, and in 1956-1957 as Senior Research Fellow in Therapeutics in Edinburgh he returned to Natal in South Africa where he was to spend the rest of his life. How did Cleave and Campbell come to work together when Campbell was in South Africa and Cleave in England? What was Campbell's contribution to the fibre story?

Campbell was a physician whose main expertise was in diabetes, which contrary to opinion at the time, he encountered regularly in both the Indian and Zulu populations of Natal. He set up the first diabetic clinic in Durban in 1958 and attracted 650 patients in the first 18 months ${ }^{(24)}$. He successfully combined dietary management with insulin and oral hypoglycaemic agents. Campbell went on to write extensively about diabetes and its treatment in Africa and spent a lot of time with the local Indian and Zulu populations finding appropriate management policies for people who were essentially very poor, lived on high-carbohydrate diets, and in the case of the Indians had problems of obesity. Campbell was a man of wide interests, which extended beyond diabetes. He was one of the first people to warn that the drug that eventually became known as Thalidomide might not be safe for human use ${ }^{(25)}$, was a reputable marine biologist writing a series of papers about shark attacks, spoke fluent Zulu and Xhosa and was a Fellow of the Royal Society of South Africa.

It is likely that Campbell's name came to Cleave's attention through Campbell's writings on diabetes. By the end of 1961 Campbell had published eight letters or papers in the British Medical Journal and the Lancet about diabetes in Natal Indians and the Zulu, which most likely would have been read by Cleave.

\section{Cleave and Campbell}

On 1 December 1962, Cleave wrote to Campbell sending him a book and asking if he would co-operate with him in writing about diabetes. Cleave's letter is lost but Campbell's reply of 6 December 1962 is available ${ }^{(26)}$. The book was about peptic ulcer and was the most recent book that Cleave had written ${ }^{(27)}$. Campbell replied to Cleave that it would be both a pleasure and an honour to work with Cleave and so they started to collaborate (Fig. 2). Although they did not meet until 1966, Cleave declining repeated invitations to visit South Africa, they worked together on both the $1966^{(21)}$ and $1969^{(23)}$ editions of The Saccharine Disease and into $1971^{(28)}$. But by the publication of the 1974 edition Cleave had dropped all co-authors to his book although acknowledged Campbell in the preface for his '... excellent racial studies in diabetes and coronary thrombosis ${ }^{(22)}$. However, their collaboration was fruitful in other ways. Campbell's interest in diabetes, further stimulated by Cleave, led him in 1969 to embark on a series of studies of the blood glucose response to carbohydrate digestion that preceded the work of others and the concept of the glycaemic index. Campbell recruited healthy volunteers and fed them $50 \mathrm{~g}$ of carbohydrate from white or wholemeal bread, apples, maize starch, sucrose and glucose. He ranked the various carbohydrates according to the AUC of blood glucose $v$. time noting that sucrose was not the top of the list and gave a paper about this at the Congress of the 


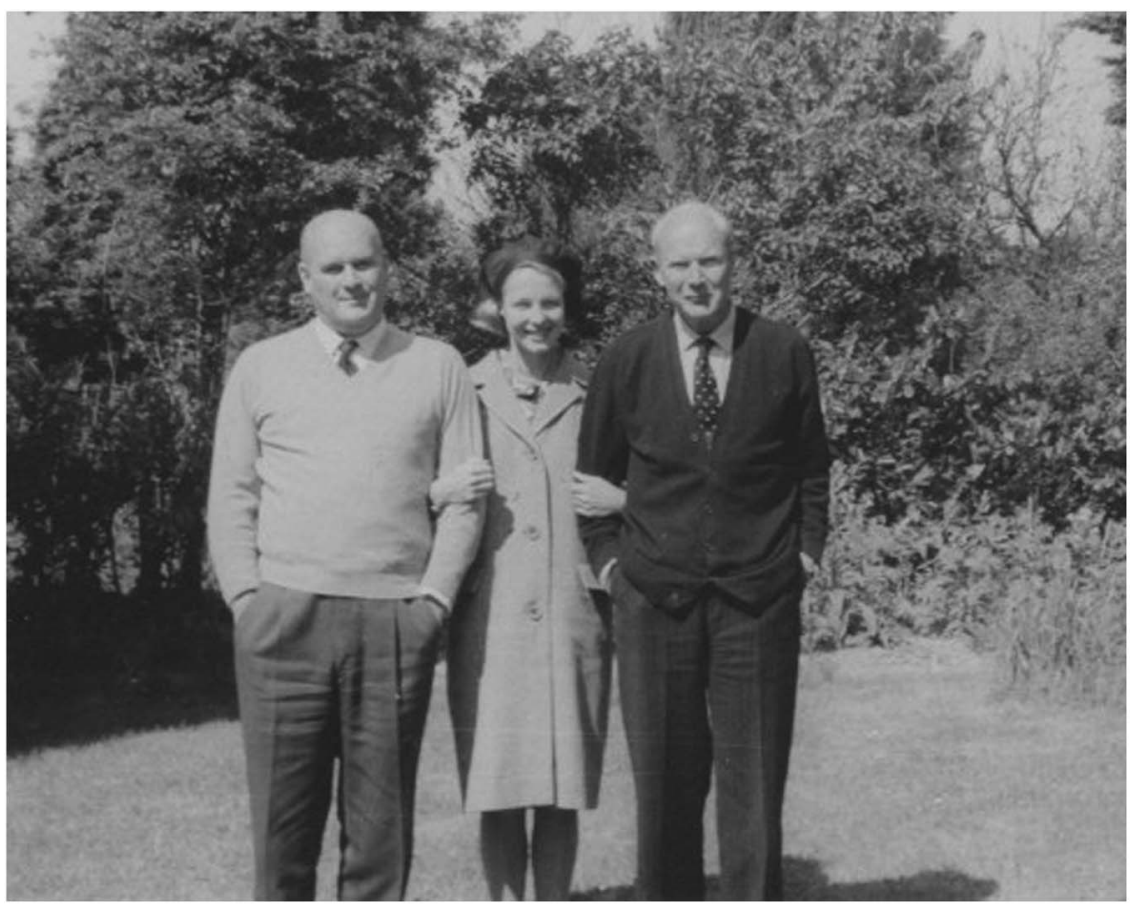

Fig. 2. G. D. Campbell, Magda Campbell his wife and Peter Cleave. Taken by Helen Cleave in the garden of the Cleaves' house in Fareham, Hampshire, circa 1970. (Courtesy of the Wellcome Library Archive.)

International Diabetes Federation in Amsterdam, $1971^{(26)}$. These studies, of what was to become known as the glycaemic index of a food, preceded by a number of years the betterknown work of Phyllis Crapo in the USA ${ }^{(29)}$ and David Jenkins in Canada ${ }^{(30)}$.

Campbell believed 'passionately that diabetes was somehow related to sugar' (Jim Mann, University of Otago, personal communication, 2015), but almost certainly fibre was not on the agenda of either Campbell or Cleave in 1966. This can be said despite Campbell's assertion of the importance of fibre in his later paper on the history of the 'saccharine disease' concept, which includes a trenchant account of his own contribution ${ }^{(31)}$. Furthermore, there is no mention of fibre in the chapters on diabetes and CHD in the 1966 book or in their early correspondence $^{(26)}$.

By 1969, Cleave had modified his ideas somewhat although he was never to subjugate sugar to fibre in his thinking. In the 1969 edition fibre gets several more mentions, although again does not appear in the index. The emphasis remains on refined foods and overconsumption but removal of fibre as a consequence '... of the refining of carbohydrates', is now stated as giving rise to a number of conditions, as can be seen from the changes shown in Table 1. Fibre has clearly arrived on Cleave's horizon and his ideas are being modified, not by Campbell but possibly by Burkitt, whom he met in late 1967. However, the second edition (1969) is published with 'the assistance of' Neil Painter and a new chapter on diverticular disease. How much was the new emphasis on fibre due to Painter whose work on diverticular disease Cleave was already aware of even before the publication of the 1966 edition of his book? Was Painter the real pioneer of the fibre story?
Neil Stamford Painter, MS (London), FRCS, FACS (1923-1989)

Neil Painter never travelled the world like Cleave, nor did he work in Africa like Burkitt, Trowell, Campbell and Walker but he had fibre firmly in his mind from early in the 1960s. After serving as a fighter pilot in the Fleet Air Arm he trained as a surgeon. In 1959, he became senior registrar to gastroenterologist Dr Sydney Truelove in Oxford where, using a newly developed technique, he measured intraluminal pressures in the sigmoid colon of patients with diverticular disease. Diverticular disease of the colon is a common condition increasing with age and consists of protrusions of the inner lining of the bowel through the wall usually between thickened layers of muscle fibres (diverticulosis). The commonest symptoms are abdominal pain and a change in bowel habit but the diverticula may become inflamed (diverticulitis), bleed and perforate. Painter showed that under resting conditions there were no differences in pressures between those with diverticulosis and healthy colons but when morphine was given there was a greater increase in pressure in those segments bearing diverticula ${ }^{(32)}$. Since morphine was used at that time to treat the pain of diverticular disease he pointed out that this might not be the best approach ${ }^{(33)}$ (Fig. 3).

Little was known about the cause of diverticular disease of the colon at this time and treatment of the uncomplicated condition was with a low-residue diet, which equated to a low-fibre diet. However, Painter argued in his MS thesis ${ }^{(34)}$ and his Hunterian lecture to the Royal College of Surgeons in $1963^{(35)}$ that diverticula were the result of localised high pressures developing in segments of the colon. In the paper and thesis he cites work published in 1949 by Carlson \& Hoelzel $^{(36)}$. In a lifetime study of rats they showed that when 


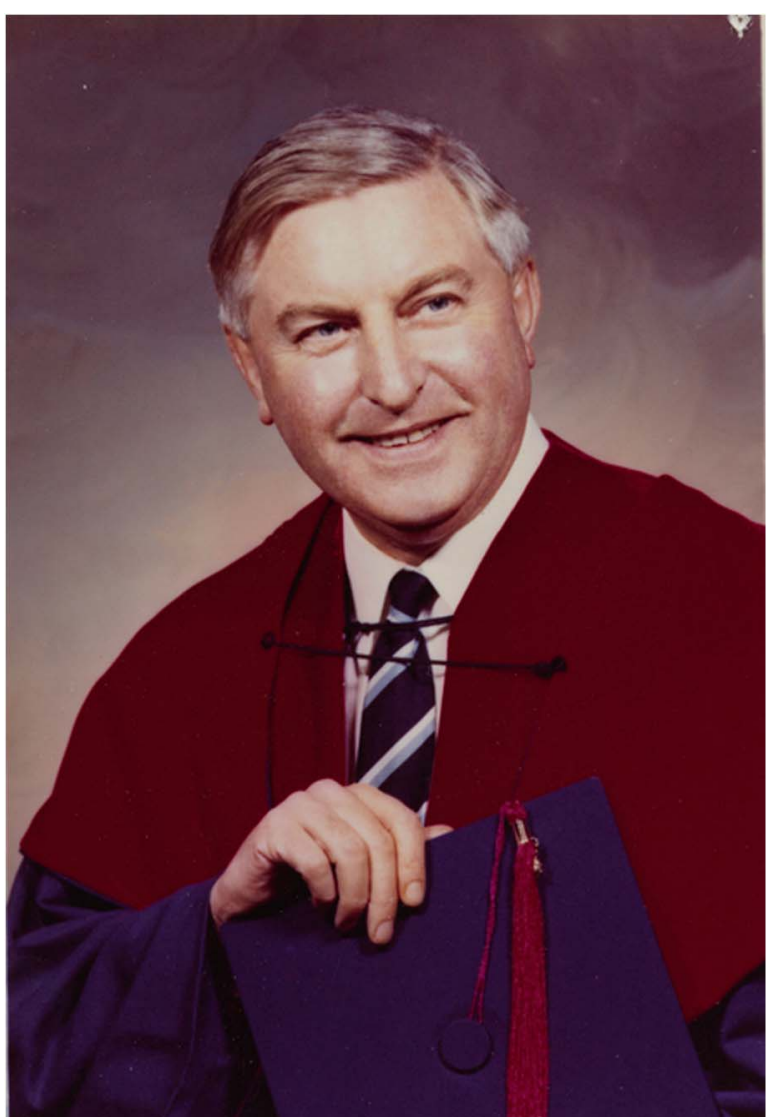

Fig. 3. Neil Painter. Probably taken at the time of his graduation as MS from the University of London in 1962. Wellcome Images L0041524.

fed a low-residue diet they developed narrow colons and diverticula but when dietary bulking agents, such as psyllium, cellulose or various gums, which can be considered to be fibre, were added to the diet the diverticula did not occur. Painter pointed out that little was known about the diet of patients with diverticular disease but he was aware from the literature that Africans seldom developed it, had wide colons and ate a bulky diet $^{(37)}$. Painter concludes his thesis in 1962 by saying that 'It maybe surmised that a low residue diet leads to narrowing of the colon and that this allows segmentation and subsequent pressure production to occur more frequently. ...From observation of African colon, which are usually more distended and do not get diverticular...It is therefore possible that a bulky diet lessens the probability of segmentation occurring and hence prevents onset of diverticulosis. ${ }^{(34)}$ It is unlikely that at this time Painter realised the full importance of fibre for other diseases but through his work on the pathogenesis of diverticular disease he had clearly identified bulk in the diet as important. On returning to full-time surgical practice as consultant at the Manor House Hospital in Golders Green London in 1965, Painter started to treat his patients with Normacol, which contains 'sterculia', a vegetable gum from the karaya tree that has established properties as a fibre laxative.

Cleave was aware of Painter's work from his avid reading of the literature and had cited it in the first edition of his book ${ }^{(21)}$. Since Cleave had used bran to treat constipation in sailors in the
Royal Navy there was clearly a common interest between Cleave and Painter. They met for the first time in 1966 and the outcome of their discussions was that Painter would write a chapter for the next edition of '...the Saccharine Disease'. Cleave instilled into Painter the notion that the refined diet of 'Western society' could also be responsible for other diseases $^{(38)}$.

When the second edition of Cleave's book was published in $1969^{(23)}$ the new chapter on diverticular disease was a poor apology for Painter's ideas and was written largely by Cleave himself with perhaps two paragraphs from Painter's hand concerning the neurophysiology of pressures in the colon that Painter had proposed as a result of his Oxford work. Cleave largely avoids the use of the term 'fibre' and talks about low-residue and high-residue diets and that diverticular disease is 'a manifestation of the saccharine disease'. Perhaps further trying to endorse the overarching importance of his theory he goes on to suggest that 'the removal of fibre... leads, via overconsumption, ... to abnormal numbers of $B$. coli in the gut...' which he thought led to inflammation. Painter had extensive correspondence with Cleave in the ensuing years ${ }^{(39)}$ but did not contribute to the third edition of the book ${ }^{(22)}$ and disagreed with Cleave over the aetiology of both diverticular disease and varicose veins. However, in 1967 Cleave encouraged Painter to start a clinical trial of bran in the treatment of diverticular disease.

Painter's study started in December 1967, ended in March 1971 and was reported in the British Medical Journal in $1972^{(40)}$. The effect of the high-fibre diet was to improve bowel habit, and relieve abdominal pain and distension. The study is easy to criticise. The dietary changes were multiple for these patients, there was no attempt to measure what they ate and there was no control group. Painter and his colleagues were not blinded to the treatment the patients were receiving, the questionnaire used is not defined and there is no statistical evaluation of the data in the paper. One of the referees of the paper was Richard Doll who was undoubtedly the leading epidemiologist in the UK at the time. He acknowledged that whilst the study had many faults the outcome made sense and was probably right so he had recommended publication (Richard Doll, University of Oxford, personal communication, circa 1972). However, this and Painter's earlier work led to a significant change in the management of diverticular disease and it is one of the iconic papers in the fibre story. Today fibre is still recommended for the management of this condition although uncertainties about the quality of the evidence from clinical trials remain ${ }^{(41)}$

Was Painter just another enthusiast in the long line of people who believed in the beneficial effects of bran? His work with Truelove on the pathogenesis of diverticula in the sigmoid colon was original as was his conclusion that the true cause was likely to be dietary and that '... a bulky diet... helps to prevent the onset of diverticulosis ${ }^{(34)}$. His recommendation to treat diverticular disease with a high-residue (fibre) diet was a turning point since the mainstay of treatment for the previous 100 years had been a low-residue diet, as was his demonstration that morphine, traditionally used for pain relief in this condition, was likely to make the patient worse. Perhaps Painter was the first to suggest to Cleave that fibre, more than just bran, 
was important in its own right in the diet whilst Cleave widened Painter's horizons regarding a group of diseases that might have a common cause. Painter undoubtedly contributed to the final fibre hypothesis and influenced Burkitt's thinking. But before Cleave, Campbell or Painter had turned their minds to fibre there was a biochemist in South Africa who had started to study the importance of fibre beyond bowel disorders to include CHD and other diseases afflicting Western populations ${ }^{(42)}$.

\section{A. R. P. Walker PhD, DSc (1913-2007)}

Alec Walker was a Scotsman with degrees in chemistry and physics who emigrated to Southern Africa in 1938, joined the Municipal Department of Health, Johannesburg in 1939 and started a lifetime of research into disorders he thought were related to diet, poor nutrition and prosperity ${ }^{(43)}$. His first publication appeared in 1943 and over 900 papers, letters and editorials later the last one, on the health benefits of vegetable and fruit consumption, was published in 2006 when he was aged 92 years. Working at the South African Institute for Medical Research on $\mathrm{Ca}$ metabolism he was the first person to show that the body adapts to low $\mathrm{Ca}$ intakes by increasing absorption ${ }^{(44)}$. He studied the prevalence of atherosclerosis and CHD in contrasting South African populations and published a series of papers from 1948 onwards on CVD and the role of fat, cholesterol and essential fatty acids. He combined epidemiology with laboratory work and human feeding trials and worked with a boundless enthusiasm coupled with an open and lively mind.

Walker first mentions fibre in $1947^{(45)}$. His interest was triggered by the widespread use of laxatives in many countries to correct what he calls an 'inadequate bowel movement'. He cites as a cause of this the change in diet from one in which large amounts of bread containing most of the bran were consumed to one with almost no bran, the result of the introduction of roller milling towards the end of the nineteenth century. This allowed white bread with little fibre to be produced cheaply, but was coupled with a halving of bread intake, which accompanied increasing prosperity. He mentions his own studies, never published, on the beneficial effects of bran on bowel habit and that of Cleave ${ }^{(16)}$ and refers to important earlier work described in the classic papers of Williams, Olmsted, Cowgill and Anderson on the mechanism of the bulk-forming (laxative) capacity of various sources of fibre ${ }^{(46,47)}$. Walker concludes his 1947 paper by recommending the permanent adoption of bread made from intermediate extraction flour, which he says will ameliorate the present state of unhealthy bowel function.

With fibre now in his thinking, Walker began to look again at his work on fat absorption ${ }^{(48)}$. In 1954, he reported, as part of his studies of diet and atherosclerosis, the results of a dietary fat intake and serum cholesterol study involving several hundred South Africans of different ethnic backgrounds ${ }^{(49)}$. Although black South Africans living in Johannesburg ate a higher fat intake than their rural counterparts, their serum cholesterols were much lower than expected. 'Summarizing, of the dietary factors, our impression is that, apart from low fat intake, there is a factor or factors in the pattern of diet of the Bantu possibly related to its high fibre content which bears some responsibility for the low serum cholesterol values observed.' This was an original observation and prompted Ancel Keys, of the University of Minnesota (USA) and the doyen of studies of diet and heart disease at this time, to do experiments on cellulose and pectin and their effects on serum cholesterol ${ }^{(50)}$. Similarly Walker's work may also have made David Kritchevsky of the Wistar Institute, Philadelphia, think about the diets he was giving to his animal models of atheroma ${ }^{(51)}$. Walker's studies indicate clearly that fibre, atherosclerosis and CHD were under investigation before 1960 and that he had begun to realise that the fibre story was not simply confined to its effects on bowel habit but included 'diseases of civilization' including caries, diabetes, CHD and lung cancer ${ }^{(52,53)}$.

Walker continued his interest in bowel diseases and had read Wynder \& Shigematsu's 1967 paper on the possible environmental causes of large bowel cancer ${ }^{(54)}$. Intrigued by their suggestion that the composition of the contents in different parts of the large bowel and variation in contact time between faeces and bowel mucosa may be determined by diet he set out to measure transit time, which is the time it takes material to pass through the gut, in his African populations. Using a non-absorbable red dye, carmine, and later the technique of radio-opaque pellets ${ }^{(55)}$, he showed that transit is much quicker in the South African blacks than their Caucasian counterparts and that bowel cancer is rarely seen in the black population $^{(56)}$. By July 1970, he had submitted to the South African Medical Journal a paper entitled 'Diet, bowel motility, faeces composition and colonic cancer' ${ }^{(57)}$ in which he reports his own work on bowel transit and earlier observations on diet together with 'contributions' by others on the topic to propose a role for fibre in the prevention of large bowel cancer. Dismissing other hypotheses such as the role of food additives, Walker suggests that the high-fibre diets of the Africans lead to faster transit of bowel contents and less degradation of large bowel constituents such as bile acids. He notes the work of Aries and colleagues in London showing significant differences in the composition of the microflora in the large bowel of Ugandans with a low risk of bowel cancer compared with those in England where the risk is high ${ }^{(58)}$. His paper was eventually published in 1971, coinciding with one on a similar topic by Burkitt ${ }^{(12)}$.

Walker was a very humble and self-effacing man who recognised the importance of fibre for many diseases but would never claim precedence for this in public. Credit should be given to him for his early and original contribution to the fibre hypothesis. His interests were wide, his output of scientific papers was prodigious and to some extent his contribution has been undervalued. He met Burkitt for the first time in 1969 and they became colleagues (Fig. 4). Walker stayed with Burkitt at his family home in 1973 and 1977. They went on to co-author six papers together. It may be that the few months at the end of 1969 after they first met were key to the development of the fibre hypothesis in Burkitt's mind. But there is one other important figure in this story.

\section{Hubert (Hugh) Carey Trowell OBE, MD, FRCP (1904-1989)}

Hugh Trowell ${ }^{(59)}$ was a physician who received his medical training at St Thomas's Hospital in London. Shortly after graduation he joined the Colonial Medical Service. From 1929, 


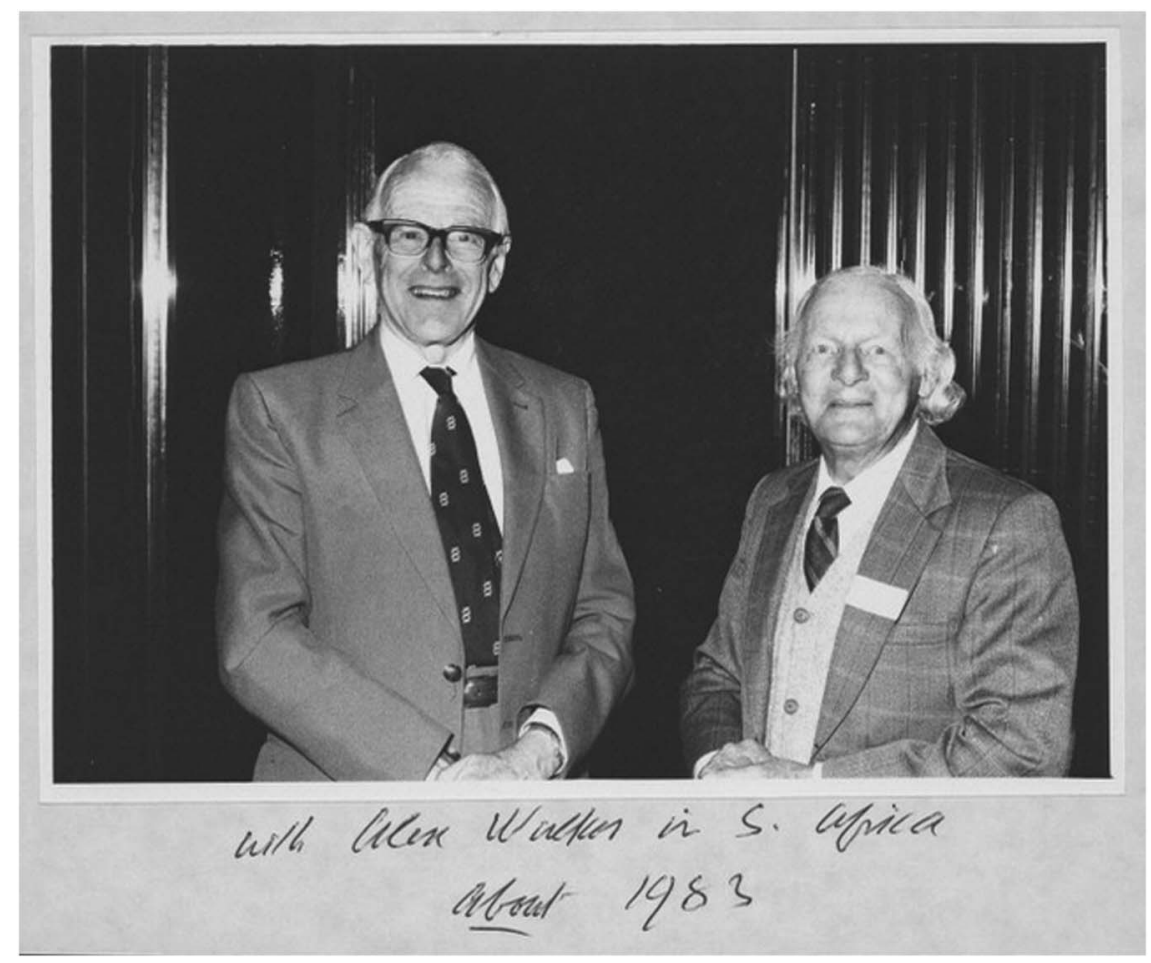

Fig. 4. Denis Burkitt and Alec Walker in South Africa 'about 1983'. Wellcome Images. (By kind permission of Olive Burkitt and Judy Howard.)

he worked in Kenya but then moved to Uganda where from 1935 to 1958 he was senior physician and paediatrician at the Mulago Hospital Kampala to which Burkitt was appointed in 1948. Trowell came to the fibre story late, after Cleave, Campbell, Painter, Walker and Burkitt, but played a significant part in its development. He was a pioneer in the treatment of kwashiorkor, was one of the first to recognise the concept of non-communicable diseases, made major contributions to the fibre hypothesis by bringing a physician's view, defined dietary fibre and together with Burkitt wrote a series of books and papers between 1972 and 1985 that set out in detail the hypothesis and evidence for it. He was an enthusiast, always wanted to understand what was going on around him and was a born letter-writer and editor.

Whilst Trowell was at his first posting in Kenya in 1929, he had seen a form of severe malnutrition in young children ${ }^{(60)}$ but thought it was pellagra ${ }^{(61)}$. Trowell had read Cicely Williams' paper published in the Lancet in $1933^{(62)}$ where she described a similar problem in young children in the Gold Coast but she was sure it was not due to vitamin B deficiency. By 1935, Williams had taken the name 'kwashiorkor' from the local people ${ }^{(63)}$, which meant '...the disease the deposed baby gets when the next one is born.... What Trowell had observed in Kenya was probably kwashiorkor but he had called it called 'malignant malnutrition' (64). He became known for his work on kwashiorkor and particularly the successful use of powdered milk in its treatment ${ }^{(65)}$. Like Burkitt, Trowell was a keen observer of diseases in Africa and in 1939 published a book on the Diagnosis and Treatment of Diseases in the Tropics(66). Fibre does not get serious consideration here although in the section on constipation he remarks that the Africans '...eat foods that contain many skins and fibres, such as beans and maize meal, and pass a bulky stool two or three times a day'. In 1957, whilst they were both working at Mulago, Trowell asked Burkitt to see a 5-year-old boy who had swellings on his upper and lower jaws. Burkitt had never seen anything like it before and began to take an interest in these tumours. Trowell is thus credited with introducing Burkitt to his first case of the lymphoma that eventually bore Burkitt's name.

Neither Trowell nor Burkitt considered fibre or diet as a major factor in any disease other than malnutrition whilst they were both in Africa but Trowell's vision was always much broader than malnutrition. On retirement in 1958 he returned to England and completed work on a book that had been in his mind for a number of years, Non-Infective Disease in Africa ${ }^{(67)}$, which is described on the inside of the cover as about 'the incidence, diagnosis and treatment of medical non-infective diseases in the indigenous inhabitants of Africa south of the Sahara'. This is a carefully researched and referenced description of the occurrence, nature, pathogenesis and treatment of diseases such as CHD, diabetes, peptic ulcer, hypertension, and bowel and urinary tract disorders. There is no significant discussion of diet or fibre in relation to these conditions although in the section on the large bowel he refers to the bulky stools of the Africans again and in the section on constipation he notes that the African's natural diet is high in fibre. He goes on to say that '...under the modern way of life...' refined foods are a large part of the diet and because more people have sedentary work their food intake is less. This along with '...a worried manner of life...' conspires to cause constipation. Trowell is clearly intrigued by the rare occurrence of these 'non-infective' conditions in Africa whilst they were major problems in Europe and North America, 
but has no ready explanation. In the closing chapter of the book he talks about the 'African milieu interior...' and the role of inheritance as causal, but he says that many diseases cannot be explained this way and that variables in blood and urine such as serum cholesterol, uric acid, blood sugar, serum Fe and clot lysis time are all very different in the African. Except in the context of kwashiorkor and malnutrition there is very little suggestion that diet in adult life is involved and it is clear that the fibre story was not part of Trowell's thinking in 1960. But the concept of 'non-infective diseases' is original, evolving into diseases of civilisation, then 'Western diseases' ${ }^{,(68)}$ and is the forerunner of the now essential concept in public health nutrition of 'non-communicable diseases' ${ }^{\text {(69) }}$ (Fig. 5).

Following the completion of his book, Trowell decided to follow another ambition of his, to become ordained. He undertook a year-long course in 1959 at Wells Theological College, spent a further year as curate in Cirencester then in 1961 became vicar of Stratford-sub-Castle in Wiltshire and Chaplain to Salisbury Hospital. He gave the next 9 years to matters concerning ethics in medicine and amongst other activities chaired a group formed by the British Medical Association on euthanasia but always had 'another mistress' (Thorold Masefield, former Governor of Bermuda who married Hugh Trowell's youngest daughter Jenny, personal communication, 2015) and that was diet, which was regularly a topic of conversation at family meal times. He relinquished his clerical appointment in August 1969. Within a few weeks he received an invitation to return to Uganda the following year to the Centenary Celebrations in honour of Sir Albert Cook,

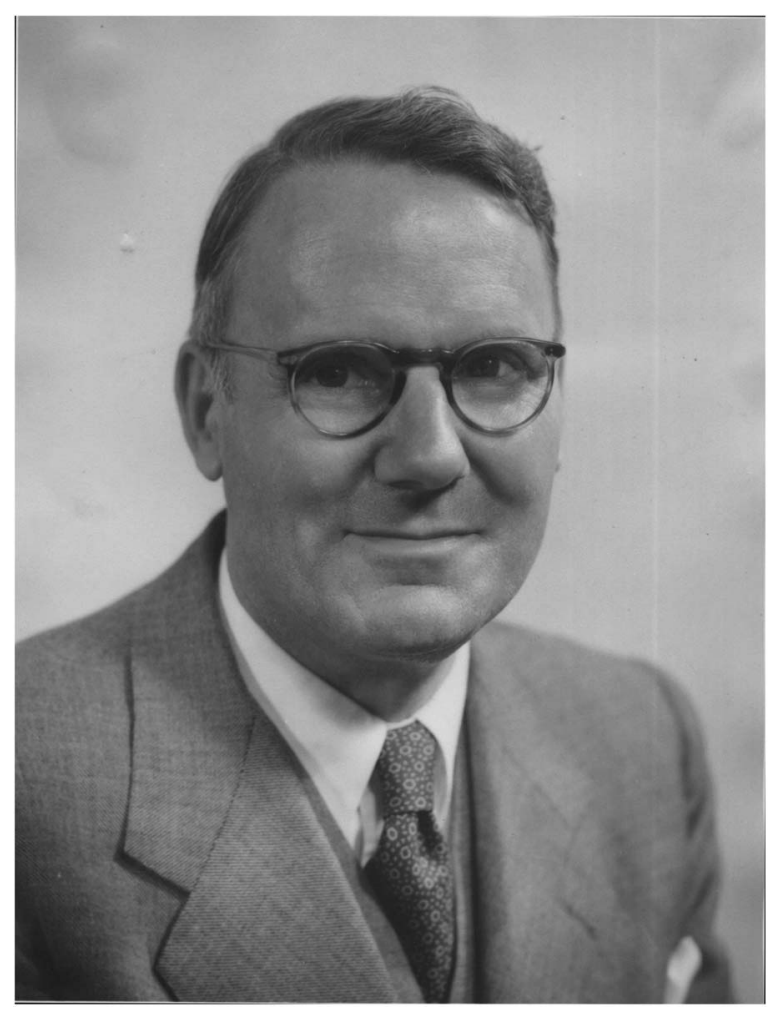

Fig. 5. Hugh Trowell taken in the early days of his time in Africa, circa 1950. (By kind permission of Thorold Masefield and Margaret Bray.) a courageous pioneer medical missionary. There he met his former colleague Burkitt once again and heard him lecture not on lymphoma as everyone expected but on his views of fibre and bowel diseases. Their reunion was highly significant for the development of the fibre story.

\section{Denis P. Burkitt CMG, MD, FRCS, FRS (1911-1993)}

There was probably no single Eureka moment in the development of the fibre hypothesis but, more likely, as is the usual case with great ideas, a gradual coming together of many lines of evidence. By 1966, when Burkitt returned from Africa, a larger fibre concept beyond that of bran and bowel habit was already in the mind of Walker, which included atherosclerosis and CHD whilst Cleave and to a lesser extent Campbell were stressing the role of refined carbohydrates, namely sugar and starch, in the cause of a wide range of diseases. Painter had published his ground-breaking studies of fibre and diverticular disease whilst Trowell had put down a marker with his 'non-infective diseases' concept but was fulfilling his role as a clergyman at this time. Over the next 5 years Burkitt, in discussion with all of these people and many others, put the pieces of the fibre story together, added to it from his own wide experience, carried out some experimental work on bowel function and was finally responsible for telling the world about it.

But on his return to the UK, diet, let alone fibre, was not in his thoughts. He continued his work into the geographical pathology of cancer, funded by the MRC, who put him in touch with Professor Richard Doll who was known for his work on lung cancer and smoking but also the links to cancer of asbestos and radiation. Doll had just, in 1966, been made a Fellow of the Royal Society and was in the process of organising a meeting in Nairobi to gather data on cancer incidence in different populations. Burkitt found in Doll someone with whom he had a common interest, and of course Burkitt already had the distinction of having a cancer named after him. In April he met Doll and Harold Himsworth, Secretary of the MRC, who agreed to Burkitt's proposal for small cancer registries to be started and financed, mostly in poorer parts of the world. Burkitt believed that great ideas always came from small beginnings. He was to meet Doll frequently over the next few years whilst pursuing the collection of data on the geography of cancer but he also began to enquire about the occurrence of other diseases. At this time he was 'receiving information monthly from over 140 mainly rural hospitals in Africa and the Indian sub-continent, ${ }^{,(70)}$ (Fig. 6).

Throughout 1966 and until 14 September 1967, Burkitt was focused on anything but diet. However, he recalls that 'I was sitting in my office... (when) the 'phone rang, and the brief conversation that followed was to be the beginning of a succession of events which were to reshape my research interests and entirely alter the direction of my endeavours.' He had been telephoned by Richard Doll who said that he had someone in his office whom he thought Burkitt would like to meet. That person was Captain T. L. Cleave. Of their meeting that day Burkitt remarks in his personal diary, which he completed daily, 'Time and chance happen to all men.' It was clearly a momentous meeting ${ }^{(71)}$. 


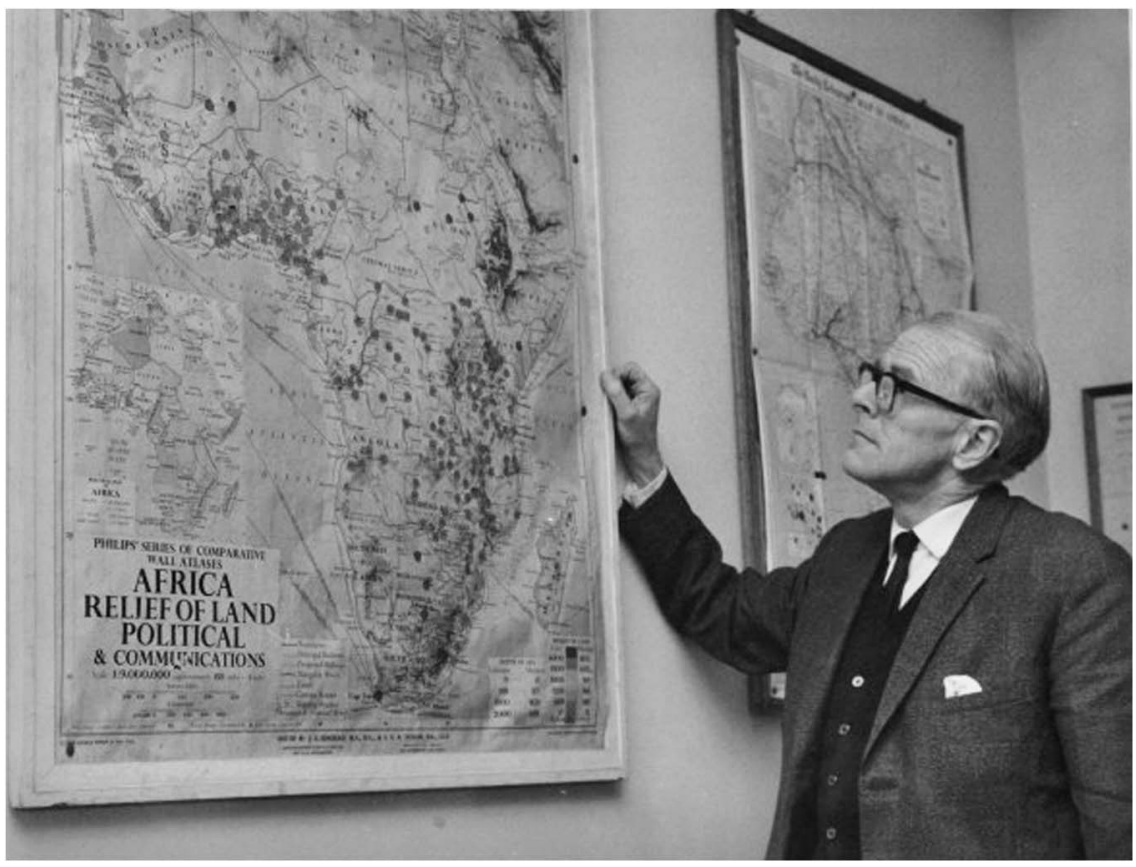

Fig. 6. Denis Burkitt at his Medical Research Council Office, 172 Tottenham Court Road, London, circa 1968. Wellcome Library Archive. (By kind permission of Olive Burkitt and Judy Howard.)

What did Cleave say to Burkitt and what was his influence on the development of Burkitt's ideas? There is no other record of their first meeting but Cleave was always a strong advocate and defender of his 'Saccharine Disease' theory and would most probably have expounded on this to Burkitt. It is clear from Burkitt's subsequent writings that he did not wholly subscribe to the sugar story and being a surgeon he was primarily interested in the bowel and in cancer. But he did take one fundamentally important message from Cleave, namely that when a group of diseases occur together geographically or in the same individual, no matter how disparate their nature, they most likely would have a common cause. Burkitt makes no reference to Cleave in his 1968 papers and may not have read Cleave's book until 1969 but he met and corresponded with him and started to take an interest in other disorders of the large bowel and in varicose veins, the origins of which Cleave thought lay in the effect of a refined carbohydrate diet on the bowel. Throughout 1968 Burkitt travelled widely, lecturing about his lymphoma, gathering data from his contacts in Africa and meeting frequently with Doll to work on the establishment of cancer registries.

A year after his first encounter with Cleave another significant meeting occurred. Burkitt gave a lecture to the British Society of Gastroenterology Annual Meeting in London in November 1968. Also speaking was Neil Painter who was by now well known for his work on diverticular disease. He had published a substantial and definitive review in the British Medical Journal in August that year ${ }^{(72)}$ and after the meeting Burkitt wrote to Painter saying, 'I was very interested in your comments suggesting a relationship between diet and diverticular disease...particularly...the work on rats fed with low and high residue diets.... ${ }^{(73)}$ These studies had been carried out in the USA and reported in $1949^{(36)}$. They were cited by Painter in his early papers but clearly had not been seen by Burkitt. The two met in January 1969, and on numerous occasions subsequently, eventually co-authoring seven papers mainly on the topic of diverticular disease ${ }^{(74)}$. Thus by early 1969 fibre was on Burkitt's agenda and he records in his diary in February that he is '.... well into planning the testing of Cleave's hypothesis'.

The test he had in mind was to measure gut transit time. This parameter of gut function has interested gastroenterologists and physiologists for generations, but why did Burkitt decide to use it? Principally it was because of Walker's work in South Africa and the growing belief that diet, particularly fibre, affected large bowel function, of which transit time is a useful measure. Using the red dye carmine as a marker Walker had shown that '...the time of passage with the Bantu is found to be shorter, often about one-half that of white subjects ${ }^{(56,75)}$. Contemporary with Walker were John Higginson and George Oettle of the South African Institute of Medical research who had gathered together the first data on cancer incidence in 'South African Bantu and "Cape Colored" Races' and had noted that constipation and bowel cancer were rare in in the Bantu whilst being common in the West, and that in Africa 'a large amount of roughage is normally consumed, and constipation in the Western sense is rare $^{,(76)}$. George Oettlé was a good friend of Burkitt. They shared a common faith and met frequently at meetings around the world where they would both attend church and the Christian Medical Fellowship. Oettlés in-depth knowledge of cancer mortality data in South Africa and interest in dietary habits were quite likely to have been a topic of conversation.

Also thinking along these lines was Ernst Wynder of the Sloan-Kettering Institute for Cancer Research in New York. He had published, with Takao Shigematsu, a major study of the epidemiology of cancer of the colon and rectum worldwide and of the environmental factors that might be important ${ }^{(54)}$. 
In a large retrospective case-control study they measured diet and bowel habit, concluding, 'On the basis of the total epidemiologic evidence... dietary factors appear to be associated with the etiology of cancer of the large bowel.' They do not mention fibre probably because no food table data existed at this time listing dietary fibre values. However, they did say that the composition of the contents of the bowel at different points might be important in determining cancer risk and in particular 'to a variation in contact time between feces and bowel mucosa', a clear reference to transit. They also suggest, 'It would be of interest to undertake comparative studies of the bacterial flora of Japanese and American patients.' It is likely that Burkitt was introduced to these two important concepts for the cause of bowel cancer, through diet relating to transit (contact time) and the gut flora, on one of his many visits to South Africa, possibly December 1968. Burkitt probably did not meet Wynder until September 1969 when Burkitt received the Judd Award but must have been aware of his papers.

Thus, the scene was set early in 1969 for Burkitt to focus on his quest for the cause of large bowel cancer. Being a surgeon he had a natural interest in bowel diseases and having already solved the problem of the lymphoma in children clearly thought that he could do the same for another cancer. He knew that there were major differences in large bowel cancer incidence between Africa and Western Countries but he needed to understand more about large bowel function in these populations. First he had to learn how to do transit studies. It was a significant change in direction in his thinking from the lymphoma. In his personal diaries he notes on 20 January 1969 that after meeting Neil Painter and '... discussing diet and bowel cancer...' he then spent Thursday 30 January 'working all day on précis of Cleave's book and added comments on bowel cancer'. Then 2 weeks later he lunched with Basil Morson, the leading pathologist of the gastrointestinal tract at that time. On 28 February he visited Dr George Misiewicz, a clinical gastroenterologist and a leading gut neurophysiologist, at the MRC Gastroenterology Unit in London where he had 'discussions on bowel transit times'. Then, characteristic of Burkitt's wide-angle vision, he visited the Microbiology Unit at St Mary's Hospital, London where he 'discussed bowel bacterial counts with Prof Williams, Hill and Drasar'. This group was in the vanguard of research into gut microflora and published ground-breaking work on bacteria, bile acids and large bowel cancer in 1969 and $1971^{(58,77)}$. Burkitt was also editing his book on the lymphoma ${ }^{(78)}$ but by the middle of June 1969 he had made 'bags for bowel transit study' and then proceeded to do the first study on his family, storing collected specimens in the home fridge and finishing by the fourth of July. He declared that he was 'pleased with results'. He then turned his attention to doing transit studies on pupils at the local school in Shiplake near to where he and Olive had bought a house, The Knoll, in $1968^{(71)}$.

Burkitt was, however, already thinking beyond bowel cancer. Probably as a result of his discussions with Cleave and Walker he was now moving towards a more all-encompassing theory of diet and disease. In June 1969, in a paper entitled 'The challenge of geographical pathology' in the Pakistan Medical Forum $^{(79)}$, he includes for the first time vascular conditions, under which heading coronary disease is mentioned, inflammatory and toxic conditions, diabetes, peptic ulcer and other large bowel diseases. He acknowledges Cleave and Campbell, citing the new 1969 edition of their book, and Oettlé and Painter amongst others. Then in December 1969, in a paper in the Lancet entitled 'Related disease - related cause ${ }^{\text {(80) }}$, for the first time he incriminates a 'low-residue diet as a major aetiological factor'. What he gives Cleave credit for is that in the study of diseases and their epidemiology '...no matter how apparently divergent, if consistently related geographically or chronologically, are likely to be related to a common aetiological factor'. The diseases he discusses in the Lancet are confined to those of the large bowel. In trying to explain what the common factor is he goes for 'stool bulk and content, bacterial flora, total transit-time and intra-lumen pressures...', all related to the removal of 'unabsorbable fibre' from the diet. Sugar gets only a passing mention because Burkitt was never convinced by Cleave's ideas on this and history has shown Burkitt to be right, especially for large bowel diseases where fibre dominates the physiological function of the bowel and is a major determinant of microbial metabolism ${ }^{(81,82)}$ whereas sugar has none of these effects. Walker's work is not mentioned here.

Determined to obtain evidence for his developing ideas, Burkitt pursued his transit studies and in March 1970 was back in Uganda at his old hospital in Kampala for the Sir Albert Cook Centenary meeting where he recruited twenty-six students and five staff. He then drove up-country to a Mission Hospital in the village of Amudat, Eastern Uganda, run in 1970 by David Webster in whose book about his time in Africa he describes Burkitt's visit and gives a rare insight into Burkitt's charisma, enthusiasm, energy and humility. Webster says that his few days '...with Denis were some of the most privileged of my

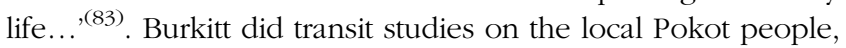
collecting three stools from each person and on the 11 March he went further into the bush to Moroto to photograph the stools of the Karamajong who lived off their more usual diet of meat, milk and blood. On the 13 March, he drove back to Kampala to get the specimens X-rayed (Fig. 7).

Back at the Centenary celebrations in Kampala he met Hugh Trowell, who had also been invited to give a lecture in tribute to Cook. Trowell toured the wards where he had once been senior physician and paediatrician and found cases of appendicitis, stroke, hypertension, CHD and diabetes that had been rare in his time and noted that many of the Africans were obese ${ }^{(59)}$. Burkitt gave a lecture on the epidemiology of diseases of the large bowel, which caught Trowell's attention. Thus it was in 1970 that Trowell, stimulated by Burkitt, began to give his mind more fully to the fibre story and the changing pattern of diseases he saw at his former hospital.

Burkitt returned to England and in April 1970 met Godfrey Milton Thompson, Professor of Naval Medicine, who was doing work on the digestion of cellulose and may have surprised Burkitt in telling him that cellulose was extensively broken down in the human gut ${ }^{(84)}$. Although this had been demonstrated by a number of scientists earlier in the twentieth century it may have been the first time that Burkitt became aware that fibre was in no way inert roughage but might be interacting with many aspects of gut function, especially the resident microflora. He puts all the ideas, which were coming to him 


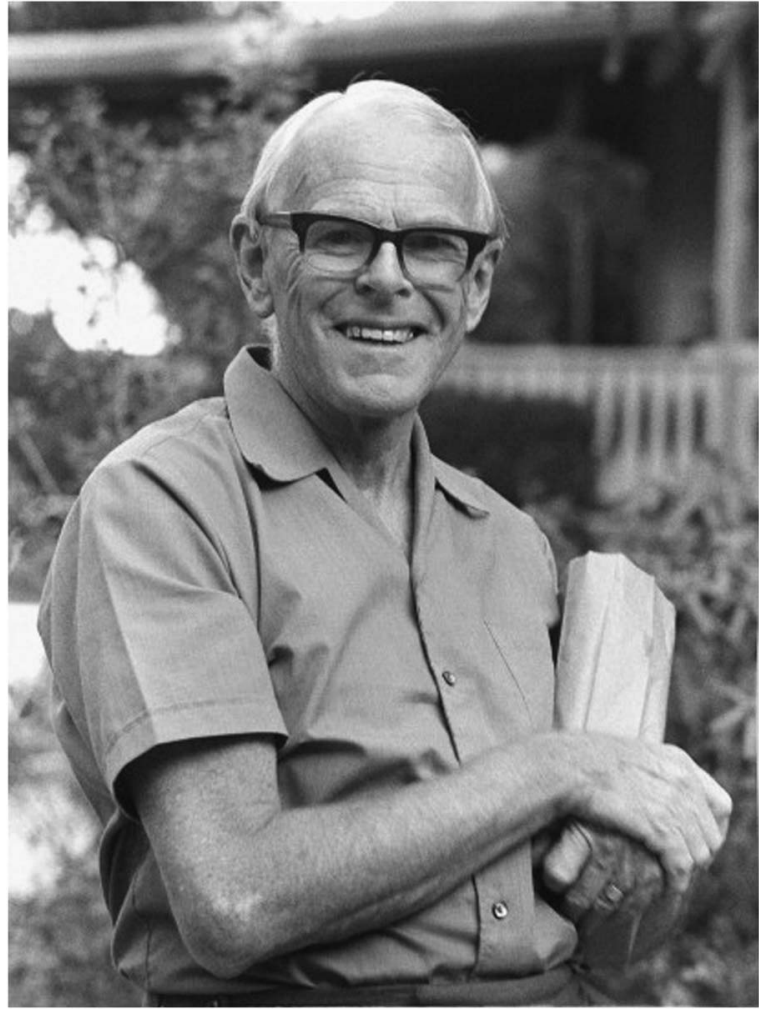

Fig. 7. Denis Burkitt in Africa, circa 1970. Wellcome Images L0040757. (By kind permission of Olive Burkitt and Judy Howard.)

from many sources, into another paper for the Lancet $^{(85)}$, published in December 1970, in which he writes that where diseases occur together geographically there is likely to be a common cause. For 'non-infective bowel diseases', a term he would have learnt from Trowell, he quite clearly invokes the role of fibre deficiency as the cause with its resultant effect on transit time, intraluminal pressures and the bacteria. For diabetes, obesity and atherosclerosis he accepts that excessive sugar intake, due to the removal of fibre from the diet, might also be important. He acknowledges Morson, Wynder, Campbell, Painter, Walker and Cleave, all of whom he had met in the previous 12 months.

Early in 1971, Burkitt attended the National Cancer Conference in San Diego, California where he gave an invited lecture about bowel diseases and the role of fibre. He wrote his presentation up as a paper for the journal Cancer ${ }^{(12)}$. The paper starts with data on the epidemiology of cancer of the colon and rectum worldwide including the information he had gathered in Africa, the association with other non-infective bowel disorders and with diabetes and atherosclerosis. He goes on to invoke diet as a possible cause and gives the results of his transit and bowel studies from which he concludes, 'There is a clear correlation between intestinal transit time and stool bulk and the fibre content of food.' He discusses possible mechanisms including effects on bile acids and bacteria in the gut and concludes that the evidence '...suggests that the removal of dietary fibre may be a causative factor'. This is another of the iconic papers in the fibre story. It became a citation classic and is Burkitt's most cited paper. Whilst the paper contains no statistics or $P$ values, it is outstanding for a number of reasons, not least of which is that Burkitt derives from the epidemiology ideas which he then tests experimentally, suggests a mechanism and then comes up with a solution for prevention.

Thus, in less than 5 years following his return from Uganda, Burkitt, through his contacts with many people, further studies in Africa and his own energy and imagination, had developed a credible hypothesis for another cancer. In 1971, Burkitt wrote about varicose veins, diverticular disease and appendicitis and later haemorrhoids and hiatus hernia. His earlier friendship with Trowell was renewed as together they developed the hypothesis that relates to not only bowel diseases but also diabetes, obesity and CHD to the consumption of low-fibre diets. In 1970, Burkitt suggested that they write a book together, eventually published in 1975, entitled Refined Carbohydrate Foods and Disease: Some Implications of Dietary Fibre ${ }^{(86)}$. But before the book could be written there was one important step to take, which was key to the final fibre hypothesis.

\section{Defining dietary fibre}

It is clear from his writings that Burkitt did not really understand what fibre was. In his 1970 Lancet paper $^{(85)}$ he uses the term fibre but also roughage, high-residue diet, unabsorbable cellulose, indigestible/unabsorbable fibre and probably was not too bothered about its exact nature. But a definition and greater understanding of fibre was important for the book he and Trowell were to write because Burkitt realised that this was a story that went beyond bran to something that had powerful effects in the gut and more generally on metabolism and was removed or destroyed by the processing of modern foods. So Burkitt asked Trowell, who by now was fully engaged in learning about fibre particularly its role in his "non-infective diseases', to find a definition of fibre that they could use. Trowell set out in search of a definition but could not find one. The word 'fibre' did not appear in the index of the main textbooks of nutrition and gastroenterology nor was there a listing for it in the Cumulated Index Medicus, the bible for researchers before the digital age. There was no book on the subject or articles in any of the leading medical journals. There were, however, some leads as to what he was looking for.

Asked in 1929 by the MRC to prepare accurate food tables to use when planning diets for diabetics, Professor R. A. McCance and Dr R. D. Lawrence of the Biochemical Department, King's College Hospital, London, noted that '...few attempts have been made to distinguish between available carbohydrate, which can be utilised and metabolised...and unavailable carbohydrate', which latter is equivalent to dietary fibre ${ }^{(9)}$. The Report contains an extensive review of the chemistry and physiology of 'fibre' that had been defined initially by the longstanding crude fibre method used by the animal feed industry since $1806^{(10)}$. Whilst crude fibre consisted mainly of cellulose, McCance and Lawrence pointed out that plant cell walls, from which fibre is derived, also contain significant quantities of pentoses. They cite the work of the physiologist Professor Max Rubner of the Robert Koch Institute of Hygiene at the University of Berlin whose experiments on the digestibility of plant cell-membrane in human subjects resulted in him 
dividing fibre into '...(a) true cellulose, (b) pentosans, (c) the residue, which latter included lignin and many other substances, ${ }^{(87)}$. McCance and Lawrence concluded that all vegetable foods contain polysaccharides other than starch, namely cellulose and the pentosans, that are broken down by '...symbiotic micro-organisms in the intestine...' and their products, the fatty acids, absorbed. They pointed out that these fibre polysaccharides were all laxative. This Report is a seminal publication and contained information about fibre and its physiological role that nutritional scientists were to rediscover only 50 years later.

Trowell and McCance knew each other through their African connections. McCance had been sent by the MRC to Uganda in 1966 to take care of the Infantile Malnutrition Research Unit in Kampala until a permanent Director could be appointed ${ }^{(88)}$. McCance had a worldwide reputation for his knowledge of food composition and had provided Trowell with information on diet whilst in Kampala. McCance returned to England in 1968 and by 1971 was retired and living in Cambridge. Trowell visited him and was advised to use the term 'unavailable carbohydrate' to describe fibre. Trowell was not happy with this since he felt that fibre was more than an unavailable component of the diet because it was broken down in the gut and had important effects both in the gut and on metabolism.

Trowell was then in touch with the British Nutrition Foundation from which he discovered that the flour millers were obliged to certify the fibre content of their flours as being indicative of their extraction rate. But the measure used was 'crude fibre'. Trowell was equally unhappy with this concept. Trowell went back to McCance in Cambridge and was told that he had refused to use crude fibre values for his food tables because of the limitations of the methodology. Whilst in Cambridge he met David Southgate who had worked with McCance since 1955 and had written his $\mathrm{PhD}$ thesis in 1965 entitled 'Carbohydrates in human faecal material ${ }^{(89)}$. Southgate was the natural heir to McCance and Widdowson in the understanding of food composition and was to take over responsibility for the UK food tables. Carbohydrate analysis of foods was still in its infancy when Southgate joined the Cambridge laboratory but as a chemist he was soon developing his own methods, based on the McCance and Lawrence concept of available and unavailable carbohydrate. At the time Trowell first approached him Southgate had just published two important papers on carbohydrate analysis, one of which was devoted to unavailable carbohydrate, which he defined as being 'not hydrolysed by any enzymes secreted into the human digestive tract ${ }^{(90,91)}$. When Trowell asked Southgate how to define fibre in a way that would have meaning for human nutrition and health, Southgate responded by saying that it was 'unavailable carbohydrate', meaning carbohydrate that escapes digestion in the human small bowel. This concept was a step away from McCance and Lawrence but provided Trowell with the basis for a definition that was inclusive of all the elements of the plant cell wall that enclosed the starch and sugars naturally present in plant foods and that were removed by the processing of food decried by Cleave.

And so it was that Trowell came up with a definition of 'dietary fibre' published in 1972 in a letter to the journal Atherosclerosis ${ }^{(92)}$. It stated that 'The skeletal remains of plant cells that are resistant to hydrolysis by enzymes of man may be called dietary fibre (DF) to distinguish it from crude fibre.' The term 'dietary fibre' had been used 29 years earlier by Hipsley in an article about pregnancy toxaemia in the British Medical Journal ${ }^{(93)}$. Hipsley says, "The term "fibre" as used in this paper includes lignin, cellulose, and the hemicelluloses.' However, Trowell does not cite Hipsley in his letter to Atherosclerosis and was probably unaware of the Hipsley paper. Trowell goes on to say that, 'It is dietary fibre, not crude fibre, that may protect against diverticular disease, appendicitis and cancer of the colon', the evidence for which he could thank Burkitt, Walker and Painter. This letter of Trowell's, which contained his dietary fibre definition, also went on to propose an extension to the fibre hypothesis, namely that fibre might lower blood cholesterol and protect against atherosclerosis and ultimately CHD. Thus, another milestone in the development of the fibre hypothesis was reached. However, the use of physiological principals, rather than chemistry as used by Hipsley, to define a component of the diet, whilst based on the ideas of McCance and Lawrence 43 years earlier, has proved to be a challenge in its measurement. When asked to recommend a method for measuring dietary fibre, Codex approved a list of seventeen in $2011^{(94)}$.

Burkitt and Trowell went on to have a successful collaboration from 1970 when they had met again in Uganda until the publication of their third book in $1985^{(95)}$. They had complementary skills, interests and got on well together and produced an overarching hypothesis that included bowel diseases, a longstanding interest of Burkitt's and the 'physicians' disorders of diabetes, CHD, venous and other conditions. The broadening of the concept of fibre beyond its effects on bowel habit captured the imagination of scientists around the world. Dr Martin Eastwood, a gastroenterologist in Edinburgh, had worked on the bile acid-binding properties of lignin in the $1960 \mathrm{~s}^{(96)}$ and went on to look at the effects of fibre on serum lipids ${ }^{(97)}$. He became a pioneer and almost lone voice for the importance of the physical properties of fibre. Also interested in bile acids was Dr Kenneth Heaton, another gastroenterologist, who had met Cleave and became convinced by the refined carbohydrate concept. He was unable to show that fibre caused bile acid binding in the gut ${ }^{(98)}$ but was more successful in studying the effects of fibre on bowel habit, transit time, satiety and in developing new ideas about the causes of gallstones. Others in South Africa, the USA and elsewhere pursued their interests in fibre, so that by the end of 1972 it was possible to describe the fibre hypothesis and conceive of a body of evidence to support it ${ }^{(14)}$.

But it was Burkitt above all others who was credited with the fibre hypothesis. In 1972 Burkitt was elected a Fellow of the Royal Society and was awarded the Lasker prize, chiefly for his work on the lymphoma giving him additional credibility as he toured the world talking about fibre. He became known as 'The Fibre Man'(13) and was a strong advocate of preventive medicine. His lectures were evangelical and illustrated by the apposite drawings of his daughter Judy.

\section{Credit to Cleave}

In the preface to their 1975 book, Burkitt pays homage to Cleave saying, '...perceptive genius in the work of Surgeon Captain T.L.Cleave to whom we wish to pay particular credit 
and acknowledge a profound debt'. But it is clear that both Burkitt and Trowell felt that dietary fibre, not sugar, was the key and the subtitle to the book is 'Some Implications of Dietary Fibre'. In a letter to Trowell dated 'Sept 26' (no year given) Burkitt says, '...it came almost as a flash of understanding that you cant (sic) have refined carbohydrate without removing the fibre, and that the fibre was the crucial thing not the sugar, ${ }^{\text {(99). }}$ In the final chapter of the book Trowell and Burkitt say that of their enquiries stimulated by the Cleave hypothesis '...they began to lay more emphasis on the beneficial effects of adequate fibre intakes and the ill-effects of fibre deficiency'. But trying to pacify Cleave did not work. After reading the book Cleave wrote to Burkitt on the 25 November 1975 saying that despite his complimentary remarks in their preface '...how can I possibly accept your arguments? ...since there is not a shred of evidence that anyone to come will be able to change my conception, $^{,(100)}$. For the rest of his life Cleave would respond vigorously to those who questioned his sugar hypothesis with long hand-written letters complete with under-linings, capitals and red ink for emphasis. Cleave was not a fibre man.

\section{An abiding truth?}

It is easy to denigrate the fibre hypothesis that postulates a simple cause and remedy for such a wide-ranging and prominent group of diseases now afflicting or emerging in most countries of the world. Its originators, with the exception of Walker, at no time would have called themselves scientists, had worked mostly in Africa, largely eschewed technology and commended simple observations and experiments. Yet 45 years on from the formative years, fibre and more particularly diets characterised by high fibre are on the agenda of most public health bodies in the world and clear recommendations for increasing fibre intakes have been given by the $\mathrm{WHO}^{(69)}$ and many national bodies. Moreover, fibre itself has been characterised in detail and been shown in a large body of human and animal experimentation to be anything but inert and non-digestible and have physiological and metabolic effects both within and beyond the gut. There is a good case to be made for fibre, or lack of it, to be considered in any theory for the cause, and thus prevention, of constipation, diverticular disease and large bowel cancer although the fibre hypothesis of Burkitt and colleagues has not perhaps been so enlightening for explaining conditions such as haemorrhoids, varicose veins, hiatus hernia, peptic ulcer and other cancers of the gastrointestinal tract. In the wider context of diabetes, obesity and CHD, fibre and more importantly diets that are "characterised by high...' fibre and contain '...increased fruits, non-starchy vegetables, nuts, legumes, fish, vegetable oils, yogurt, and minimally processed whole grains' are now regarded as key to the prevention of these conditions ${ }^{(101,102)}$. Cleave may have pointed the way with his relating this group of diseases to a common, dietary, cause but the contribution of Burkitt, the surgeon from Africa, in building the fibre hypothesis is as important now as it was in 1971. The approach, in which he created an hypothesis for the cause of a disease based on epidemiological observations, his testing of the hypothesis by experimentation (i.e. transit studies) leading to the proposal of a policy for prevention based on the totality of evidence he gathered, is a model for public health policy today.

\section{Acknowledgements}

The authors gratefully acknowledge the help of Olive Burkitt (died 13 March 2017), widow of Denis Burkitt, Judy Howard and members of the Burkitt family for invaluable oral history and access to Burkitt's personal diaries and papers; Margaret Bray, Simon Akam, Joan Trowell, Thorold Masefield and the family of Hugh Trowell for help with the archives and particularly the unpublished biography of Trowell by Elizabeth Bray; Dr Martin Eastwood for helpful discussions at an early stage of this project; Professor Jim Mann for personal recollections of G. D. Campbell; Professor Este Vorster who worked closely with Alec Walker over many years; Professor Wolfgang Scheppach for translation from the German; Professor J. M. Wilkinson for discussions on the early studies of fibre in animal nutrition; and Professor Prakash Shetty for providing the motivation for this paper. Our thanks also to the staff of the Wellcome Library for facilitating access to the archives of Burkitt, Cleave, Trowell, Painter and others, which contain records of many of the events described in this paper. This article was made open access thanks to funding from the Wellcome Trust Library Open Access Fund.

This research received no specific grant from any funding agency, commercial or not-for-profit sectors.

There are no conflicts of interest.

\section{References}

1. Burkitt DP (1983) The discovery of Burkitt's lymphoma. Cancer 51, 1777-1786.

2. Burkitt DP \& O'Conor GT (1961) Malignant lymphoma in African children. I. A clinical syndrome. Cancer 14, 258-269.

3. Burkitt DP (1951) Primary hydrocele and its treatment: review of two hundred cases. Lancet i, 1341-1343.

4. Burkitt DP \& Burkitt R (1952) Acute abdomens - British and Baganda compared. E Afr Med J 29, 189-194.

5. Burkitt DP, Nelson CL \& Williams EH (1963) Some geographical variations in disease patterns in East and Central Africa. E Afr Med J 40, 1-6.

6. Burkitt DP, Hutt MSR \& Slavin G (1968) Clinico-pathological studies of cancer distribution in Africa. Br J Cancer 22, 1-6.

7. Burkitt DP, Wilson AMM \& Jelliffe DB (1964) Subcutaneous phycomycosis: a review of 31 cases seen in Uganda. $\mathrm{Br}$ Med J 1, 1669-1673.

8. Burkitt DP (1966) A great pathological frontier. Postgrad Med J 42, 543-547.

9. McCance RA \& Lawrence RD (1929) The Carbohydrate Content of Foods, Special Report Series of the Medical Research Council no. 135. London: HM Stationery Office.

10. Van Soest PJ \& McQueen RW (1973) The chemistry and estimation of fibre. Proc Nutr Soc 32, 123-130.

11. Van Soest PJ \& Roberston JB (1977) What is fibre and fibre in food? Nutr Rev 35, 12-22.

12. Burkitt DP (1971) Epidemiology of cancer of the colon and rectum. Cancer 28, 3-13.

13. Kellock B (1985) The Fibre Man. Tring: Lion Publishing.

14. Cummings JH (1973) Dietary fibre. Gut 14, 69-81.

15. Wellcome Library, Papers of Sir Francis Avery Jones, GC/ 198/B/2/6 Heaton KW (circa 1989) Surgeon Captain TL Cleave FRCP. London: The McCarrison Society. 
16. Cleave TL (1941) Natural bran in the treatment of constipation. Br Med J 1, 461.

17. Cleave TL (1941) A Theory That any Organism is a Single Chemical Molecule: Put Forward as the Key to the Problem of the Causation of Neoplasms. London: Butterworth Heinemann.

18. Cleave TL (1956) The neglect of natural principles in current medical practice. J R Nav Med Serv 42, 55-83.

19. Anonymous (1983) Obituary: Surgeon Captain TL Cleave MRCS, LRCP, FRCP, late RN (ret). Br Med J 287, 1145.

20. Short AR (1920) The causation of appendicitis. Br J Surg $\mathbf{8}$, 171-188.

21. Cleave TL \& Campbell GD (1966) Diabetes, Coronary Thrombosis and the Saccharine Disease. Bristol: John Wright and Sons.

22. Cleave TL (1974) The Saccharine Disease. Bristol: John Wright.

23. Cleave TL, Campbell GD \& Painter NS (1969) Diabetes, Coronary Thrombosis and the Saccharine Disease. Bristol: John Wright and Sons.

24. Campbell GD \& McNeill WG (1959) Diabetes in the tropics. Br Med J 2, 73-74.

25. Murdoch JM \& Campbell GD (1958) Antithyroid activity of $N$-phthalyl glutamic acid. Br Med J 1, 84-85.

26. Wellcome Library, Papers of Peter Cleave, PP/TLC/C.1/11.

27. Cleave TL (1962) Peptic Ulcer. Bristol: John Wright and Sons.

28. Cleave TL \& Campbell GD (1971) The diet and the changing pattern of disease. Centr Afr J Med 17, 129.

29. Crapo PA, Reaven G \& Olefsky J (1976) Plasma glucose and insulin responses to orally administered simple and complex carbohydrates. Diabetes 25, 741-747.

30. Jenkins DJA, Wolever TMS, Taylor RH, et al. (1981) Glycemic index of foods: a physiological basis for carbohydrate exchange. Am J Clin Nutr 34, 362-366.

31. Campbell GD (1996) Cleave the Colossus and the history of the "Saccharine Disease" concept. Nutr Health 11, 323-329.

32. Painter NS \& Truelove SC (1964) Intraluminal pressure patterns in diverticulosis of the colon. Gut 5, 201-207.

33. Painter NS \& Truelove SC (1963) Potential dangers of morphine in acute diverticulitis of the colon. $\mathrm{Br} \mathrm{Med} \mathrm{J} \mathbf{2}$, 33-34.

34. Painter NS (1962) Diverticulosis of the colon. MS Thesis, University of London.

35. Painter NS (1964) The aetiology of diverticulosis of the colon with special reference to the action of certain drugs on the behaviour of the colon. Ann R Coll Surg Engl 34, 98-119.

36. Carlson AJ \& Hoelzel F (1949) Relation of diet to diverticulosis of the colon in rats. Gastroenterology 12, 108-115.

37. Wilson RR (1950) Diverticula of the appendix and certain factors in their development. BrJ Surg 38, 65-81.

38. Painter NS (1967) Diet and diverticulosis. Br Med J 3, 434.

39. Wellcome Library, Papers of TL Cleave, PP/TLC/C.1/8 Neil Painter.

40. Painter NS, Almeida AZ \& Colebourne KW (1972) Unprocessed bran in treatment of diverticular disease of the colon. Br Med J 2, 137-140.

41. Smith J, Humes DJ \& Spiller RC (2011) Should we treat uncomplicated diverticular disease with fibre? $\mathrm{Br} \mathrm{Med} \mathrm{J}$ 342, d2951.

42. Walker ARP (1955) Diet and atherosclerosis. Lancet i, 565-566.

43. Anonymous (1994) Alexander R. P.Walker - an appreciation. $S$ Afr Med J 84, Suppl., 1-62.
44. Walker ARP, Irving JT \& Fox FW (1946) Nutritional value of high-extraction wheat meals. Nature 3997, 769.

45. Walker ARP (1947) The effect of recent changes of food habits on bowel motility. S Afr Med J 21, 590-596.

46. Cowgill GR \& Anderson WE (1932) Laxative effects of wheat bran and "washed bran" in healthy men: a comparative study. J Am Med Assoc 98, 1866-1875.

47. Williams RD \& Olmsted WH (1936) The effect of cellulose, hemicellulose and lignin on the weight of the stool: a contribution to the study of laxation in man. J Nutr 11, 433-449.

48. Walker ARP (1949) Effect of low fat intakes and of crude fibre on the absorption of fat. Nature 164, 825-827.

49. Walker ARP \& Arvidsson UB (1954) Fat intake, serum cholesterol concentration, and atherosclerosis in the South African Bantu. Part I. Low fat intake and the age trend of serum cholesterol concentration in the South African Bantu. J Clin Invest 33, 1358-1365.

50. Keys A, Grande F \& Anderson JT (1961) Fiber and pectin in the diet and serum cholesterol concentration in man. Proc Soc Exp Biol Med (New York) 106, 555-558.

51. Kritchevsky D \& Tepper SA (1968) Experimental atherosclerosis in rabbits fed a cholesterol-free diet: influence of chow components. J Atheroscler Res 8, 357-369.

52. Walker ARP (1961) Crude fibre, bowel motility, and pattern of diet. S Afr Med J 35, 114-115.

53. Walker ARP (1962) Health hazards in the urbanisation of the African. Am J Clin Nutr 11, 551-553.

54. Wynder EL \& Shigematsu T (1967) Environmental factors of cancer of the colon and rectum. Cancer 20, 1520-1561.

55. Walker ARP \& Walker BF (1969) Bowel motility and colonic cancer. Br Med J 3, 238.

56. Walker ARP, Walker BF \& Richardson BD (1970) Bowel transit times in Bantu populations. Br Med J 3, 48-49.

57. Walker ARP (1971) Diet, bowel motility, faeces composition and colonic cancer. $S$ Afr Med J 45, 377-379.

58. Aries V, Crowther JS \& Drasar BS (1969) Bacteria and the aetiology of cancer of the large bowel. Gut 10, 334-335.

59. Wellcome Library, Papers of Hugh Trowell, PP/HCT/A.5 Elizabeth Bray, Hugh Trowell:Pioneer Nutritionist 1904-1989.

60. Trowell KM (1957) African Tapestry. London: Faber and Faber.

61. Trowell HC (1937) Pellagra in African children. Arch Dis Child 12, 193-212.

62. Williams CD (1933) A nutritional disease of childhood associated with a maize diet. Arch Dis Child 8, 423-433.

63. Williams CD (1935) Kwashiorkor. A nutritional disease of children associated with a maize diet. Lancet ii, 1151-1152.

64. Trowell HC \& Muwazi EMK (1945) A contribution to the study of malnutrition in Central Africa: a syndrome of malignant malnutrition. Trans $R$ Soc Trop Med Hyg 39, 229-242.

65. Trowell HC, Davies JNP \& Dean RFA (1954) Kwashiorkor. London: Edward Arnold.

66. Trowell HC (1939) Diagnosis and Treatment of Diseases in the Tropics. London: Balliere Tindall Cox.

67. Trowell HC (1960) Non-Infective Disease in Africa. London: Edward Arnold.

68. Trowell HC \& Burkitt DP (editors) (1981) Western Diseases: Their Emergence and Prevalence. Cambridge, MA: Harvard University Press.

69. World Health Organization (1990) Diet, Nutrition and the Prevention of Chronic Diseases. Report of a WHO Study Group, Technical Report Series 797. Geneva: WHO.

70. Wellcome Library, Papers of Denis Burkitt, WTI/DPB/F/1/1 Unpublished autobiography Chapter 13 New Horizons. 
71. Burkitt DP (1967) Personal Diaries.

72. Painter NS (1968) Diverticular disease of the colon. Br Med J 3, 475-479.

73. Wellcome Library, Papers of Neil Painter, PP/NSP, Accession no 624 Box 2 File 'Burkitt and fibre'.

74. Painter NS \& Burkitt DP (1971) Diverticular disease of the colon: a deficiency disease of Western civilisation. Br Med J 2, 450-454.

75. Walker ARP (1956) Some aspects of nutritional research in South Africa. Nutr Rev 14, 321-324

76. Higginson J \& Oettle AG (1960) Cancer incidence in the Bantu and "Cape Colored" races of South Africa: report of a cancer survey in the Transvaal (1953-55). J Natl Cancer Inst 24, 589-671.

77. Hill MJ, Crowther JS, Drasar BS, et al. (1971) Bacteria and aetiology of cancer of the large bowel. Lancet i, 95-100.

78. Burkitt DP \& Wright DH (1970) Burkitt's Lymphoma. Edinburgh: E and S Livingstone.

79. Burkitt DP (1969) The challenge of geographical pathology. Pakistan Med Forum 4, 13-18.

80. Burkitt DP (1969) Related disease - related cause. Lancet ii 1229-1231.

81. Malkki Y \& Cummings JH (editors) (1996) Dietary Fibre and Fermentation in the Colon. Proceedings of COST Action 92 workshop, Espoo, Finland 1995. Brussels: European Commission.

82. Cummings JH (1996) The Large Intestine in Nutrition and Disease. Brussels: Institute Danone.

83. Webster D (2007) The Shimmering Heat. Rushden: Stanley L. Hunt.

84. Milton-Thompson GJ \& Lewis B (1971) The breakdown of dietary cellulose in man. Gut 12, 853-854.

85. Burkitt DP (1970) Relationship as a clue to causation. Lancet ii., 1237-1240.

86. Burkitt DP \& Trowell HC (1975) Refined Carbohydrate Foods and Disease: Some Implications of Dietary Fibre. London: Academic Press.

87. Rubner M (1883) Über den wert der weizenkleie für die ernaehrung des menschen (The value of wheat bran for the nutrition of the people). $Z$ Biol $\mathbf{1 8 8 3}, 45-100$.
88. Widdowson EM (1993) Obituary Notice: R. A. McCance (9 December 1898-5 March 1993). Proc Nutr Soc 52, 383-386.

89. Cummings JH (2003) Appreciation of David Southgate. Br J Nutr 100, 690-692.

90. Southgate DAT (1969) Determination of carbohydrates in foods. II. Unavailable carbohydrates. J Sci Food Agric 20, 331-335.

91. Southgate DAT (1969) Determination of carbohydrates in foods. I. Available carbohydrates. J Sci Food Agric 20, 326-330.

92. Trowell HC (1972) Crude fibre, dietary fibre and atherosclerosis. Atherosclerosis 16, 138-140.

93. Hipsley EH (1953) Dietary "fibre" and pregnancy toxaemia. Br Med J 2, 420-422.

94. World Health Organization (2011) Report of the Thirty Second Session of the Codex Committee on Methods of Analysis and Sampling, REP 11/MAS. Geneva: WHO.

95. Burkitt DP, Trowell HC \& Heaton KW (1985) Dietary Fibre, Fibre-Depleted Foods and Disease. London: Academic Press.

96. Eastwood MA \& Hamilton D (1968) Studies on the adsorption of bile salts to non-absorbed components of the diet. Biochem Biophys Acta 152, 165-173.

97. Eastwood MA (1969) Dietary fibre and serum lipids. Lancet ii, $1222-1225$.

98. Heaton KW, Heaton ST \& Barry RE (1971) An in vivo comparison of two bile salt binding agents, cholestyramine and lignin. Scand J Gastroenterol 6, 281-286.

99. Wellcome Library, Papers of Hugh Trowell, PP/HCT/B $3 / 2$.

100. Wellcome Library, Papers of Denis Burkitt, WTI/DPB/C/5.

101. Cummings JH \& Englyst HN (1992) Plant polysaccharides and health. In Natural Resources and Human Health: Plants of Medicinal and Nutritional Value (Proceedings of the first WHO Symposium on Plants and Health for All: Scientific Advancement, Kobe, Japan, 26-28 August 1991), pp. 177-192. Amsterdam: Elsevier.

102. Mozaffarian D (2016) Dietary and policy priorities for cardiovascular disease, diabetes, and obesity: a comprehensive review. Circulation 133, 187-225. 